
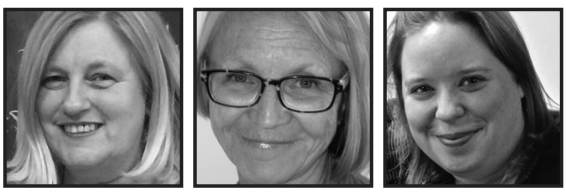

\title{
Re-locating the Self: Portraiture for Teacher Professional Growth
}

Heather Hancheruk, Judith McBride, and Kristen Witczak

\begin{abstract}
In this article, three teachers at various career-stages describe the process and share evidence of artful exploration and engagement through self-portraiture (LawrenceLightfoot \& Hoffmann Davis, 1997). The development of performance, poetic, and visual renderings of self proves empowering and transformative. Insights are gained through public presentation of portraits and involvement with colleagues as they create their own portrayals. Using literary métissage (Hasebe-Ludt, Chambers, \& Leggo, 2009) to braid voices across locations, emergent issues of vulnerability, community, and the possible contribution of teacher inquiry to knowledge of teachers, teaching, and learning are discussed.
\end{abstract}

In artful development, enforced conformity is reclaimed by self-chosen, experienced, embodied change. As teachers explore change as feeling and form, they intuitively, imaginatively, and confidently come to trust themselves as their own reliable agents of change.

- P. Diamond and C. van Halen-Faber, Apples of Change, 2005, p. 81.

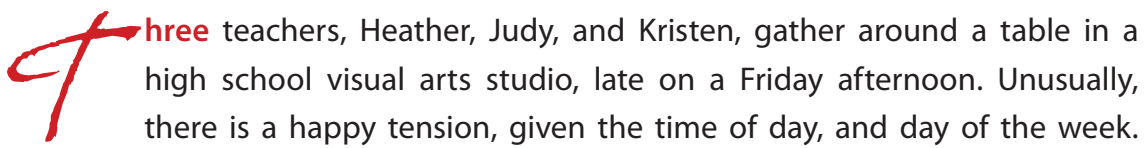

They are surrounded by the delightful clutter of a creative learning space, and are planning a workshop on the topic of self-portraiture, to be offered at their annual 
Teachers' Convention. In preparation, they are sharing self-portraits along with thoughts on the experience of creating them. Heather and Judy created mixed media collages, and Kristen, a spoken-word performance piece. Deep in conversation, deep into individual representations, deep into the project, a question arises: Why self-portraits?

Heather is a veteran art teacher, artist, and doctoral candidate. Her portrayal of herself as an art educator uses imagery from her present practice and from her early years as an art teacher, which are connected in order to represent the story of her career. Judy is a retired special education teacher and teacher educator. Her portrait is a four-paneled collage of photographs, contour drawings, and poetry representing her transformation from rookie to retiree. Kristen is an early-career English teacher and arts educator with a background in theatre. Her portrait took the form of a short performance, a reflection on her struggle for accurate self-representation. In this article we set out to explain our purpose and share our productions. Together we have embarked, somewhat serendipitously, on an expedition into the vagaries of self-portraiture, arts-based inquiry, and more importantly-and interestingly-into our selves. And, so, we braid our voices into a métissage (Hasebe-Ludt et al., 2009) and begin to answer the question:

\section{- Why self-portraits?}

Creating a portrait provides an opportunity for reflection on actions, beliefs, and outcomes. I look for an understanding of my self in my context, which I do not always have, because often when I think I know, it changes. My portrait informs and empowers me. As I look into my self, the portrait exposes and illuminates my teaching and my learning, and I am able to identify changes over time because there is evidence of who I have been, of what the road looked like at earlier times. I can consider my educative influence on students and colleagues, and find direction for furthering my endeavours both in the portrait as well as in what is not portrayed. (H. Hancheruk, J. McBride, \& K. Witczak, professional conversation, November 9, 2015)

We are engaged in personal, situated inquiry, in self-study (Hamilton, 1998; Samaras, 2011), and our portraits are as much a method as an outcome. We explore issues of personal relevance (Diamond \& van Halen-Faber, 2005) in creating products that are at once explicit and ambiguous. For example, taken at face value, Heather in her collage, is Heather (see Figure 1). Blond hair. Blue sweater. Favourite drawing pencil in hand. Canvas and landscape before her. That much is pretty straightforward. 
Nevertheless, the ambiguity of her self-portrait is there for those who wish to engage with her in the inquiry beyond the image, for those who will risk disorientation and encounters with the possible perplexities of engagement. Within that in-between space, between what is obvious and what might be learned, our evolving identities incubate. We offer metaphorical renderings of our search for understanding of who we are, of where we are located or may be headed, of our identity quests.

Our portraits allow us to locate ourselves, and create narratives to share with others that are "... at once complex, provocative, and inviting, that attempt to be holistic, revealing the dynamic interaction of values, personality, structure, and history" (Lawrence-Lightfoot \& Davis, 1997, p. 11). One purpose is disequilibrium, and we invite others to lose the way, find new locations along with us, "...to revisit the world from a different direction, seeing through fresh eyes, and thereby calling into question a singular, orthodox point of view" (Barone \& Eisner, 2012, p. 16). The locations are complex and include points in the physical world, individual, professional, personal, and psychological worlds, as well as at various points of intersection. These may be bright and vibrant, or reduced to greys. As we locate and explore parts of our selves within ourselves, we discover things not yet known. We locate, portray, give voice to, and open our selves to the perceptions of, and relationships with, others (LawrenceLightfoot \& Davis, 1997). We engage empathetically within and beyond our circle, illuminating and closing distances between us, and thereby enlarging understandings of what it means to teach, to learn, and to learn to teach (Barone \& Eisner, 2012).

\section{The Portraits}

Real art has the capacity to make us nervous.

- S. Sontag, Against Interpretation, 1966, p. 8

\section{Heather}

What sustains the passion and motivation of an art educator over the life cycle of her career? This is a big question. I asked it of myself and created a self-portrait in response. I found I couldn't answer the big question without first delving deeply into the ideas that a portrait of myself as an art teacher could provide. Smaller questions led me to the answer: Who am I as an art educator? What do I value in my teaching? What does it look like to be an art teacher? 


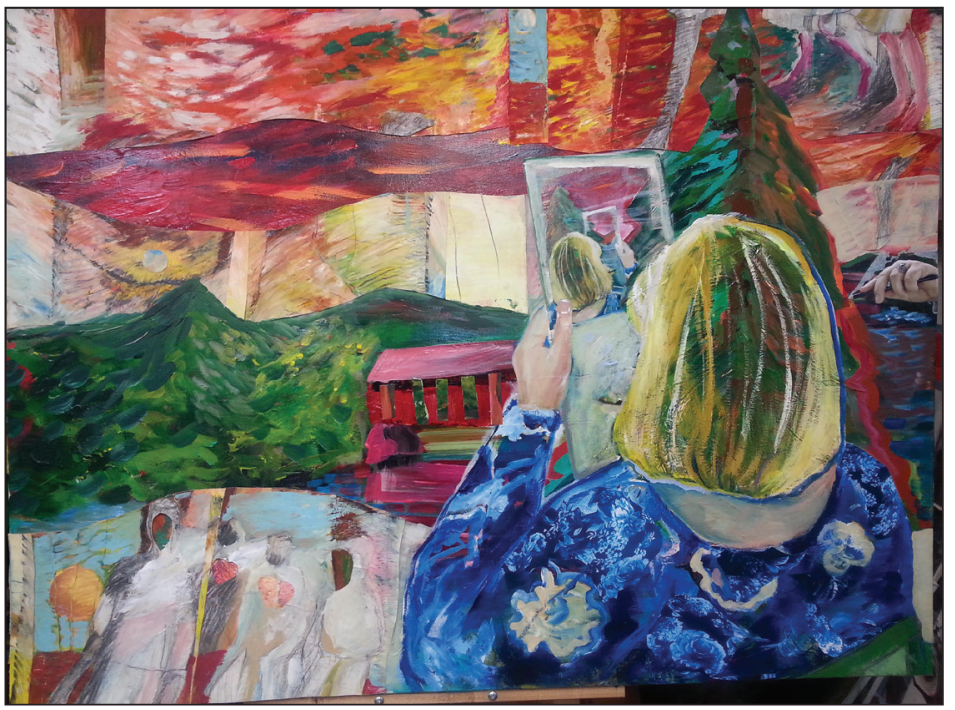

Fig. 1: Through the eyes of change

In my mixed media self-portrait you see the larger figure holding a sketchbook, in what appears to be a dual-landscape setting: the Bahamas, where I spent my second to fifth year of teaching art, and the Eastern Townships of Quebec. I love Nassau, Bahamas, and the Townships, and I appreciate the environment of my first year of teaching in Chibougamou, Quebec. A large part of who I am, and what I value, is where I am situated, what surrounds me. Trees give me energy. Water also. Pencil marks and oil paint on paper excite my senses.

In order to create my self-portrait, I took an older drawing/oil painting on paper done during my Bahamas years, cut it up, and collaged it along with parts of photographs onto the acrylic painting, in which I am painting a covered bridge in a landscape. I merged the past with the present, bridging the gap between. I am seen from the back, but my hands are implicated through a collaged photograph of a hand coming into the right side of the painting, and a hand drawing in a sketch book using a collaged pencil. The layers of collage and various media, mirrored reflections of the portrait-within-the-portrait in the sketchbook, reflect the kaleidoscopic complexity of the art teacher that I am. My career spans 30 years and I have been required to master many media, and take on many roles. I look back and remember when I had time and energy to make art more often. As time passed, I became more a teacher-of-art, and have incorporated my artist persona into that identity. I added the role of researcher further still into my career. 
The artist persona of the past is represented in collaged environments and the present in the Townships landscape. I view myself as an artist within the many artworks of thousands of students; a ghost-artist, so to speak. My students see only my hands most of the time. They are interested in what my hands can do to help them realize their work. I am a hands-on art teacher; old school, they might say. If asked, I will draw or paint for my students on their work, to show them how to accomplish something. Hence, the hands and the pencil are emphasized in this artwork.

As a researcher, I am looking at who I am and how passion and motivation for the job of art teacher are sustained over the career span. Teachers' capacity to sustain commitment and resilience are influenced by our professional life phases and identities, and these are mediated by the contexts in which we live and work (Day \& Gu, 2009). The teacher, artist, researcher, artist-teacher, and artist-researcher are confluent identities that support and edify one another, and are not mutually exclusive (Thornton, 2013). Self-study (Loughran, Hamilton, LaBoskey, \& Russell, 2007), focusing on the self as research subject and the reflexive engagement with one's own experience, provides a means to trace the career-long shifts and evolution, as well as insights into the relationship among commitment, passion, life stage, motivation, identity, and job satisfaction (Crosswell, 2006). Clearly, teacher commitment is highly personal, and the self and its relationship to education must be engaged with intimately and subjectively. Self-portraiture provides a road to insights into the intimacies and intricacies of the life of the teacher-of-art. Creating and sharing selfportraits is a stepping-stone between what I hope to achieve in my doctoral research, and my present location at the beginning of the journey to answering my questions.

\section{Judy}

Portraiture as a qualitative research method (Lawrence-Lightfoot \& Hoffmann Davis, 1997) offers intimate narratives for public consideration. Combining visual and verbal elements in a portrait moves me into the realm of light writing (Chambers, Hasebe-Ludt, Leggo, \& Sinner, 2012; Sinner, 2013), a form of arts-based inquiry (Barone \& Eisner, 2012). My living educational theory (Whitehead, 1993) embodies the core values that I bring to my endeavours as a teacher-researcher. In writing my claim to value certain things, I become self-aware, conscious of my self and of my acts. In portraying my values, I open my work to the scrutiny of others and to conversation. Such transparency gives me a mirror held up by others in which I may be seen as working true to my values, or in contradiction to the same. As an ensemble, portraiture, light writing, and living theory provide a framework within which I may continue to grow as a teacher-researcher. The portraits below are from a series of four panels entitled 
Metanoia: A portrait of transformative change of heart, that is bound by the central metaphor of the river journey that is my career, key locations on that journey. In The Cenote, I confront myself as a living contradiction (Whitehead, 1993), successful with some students, but crucially failing others.

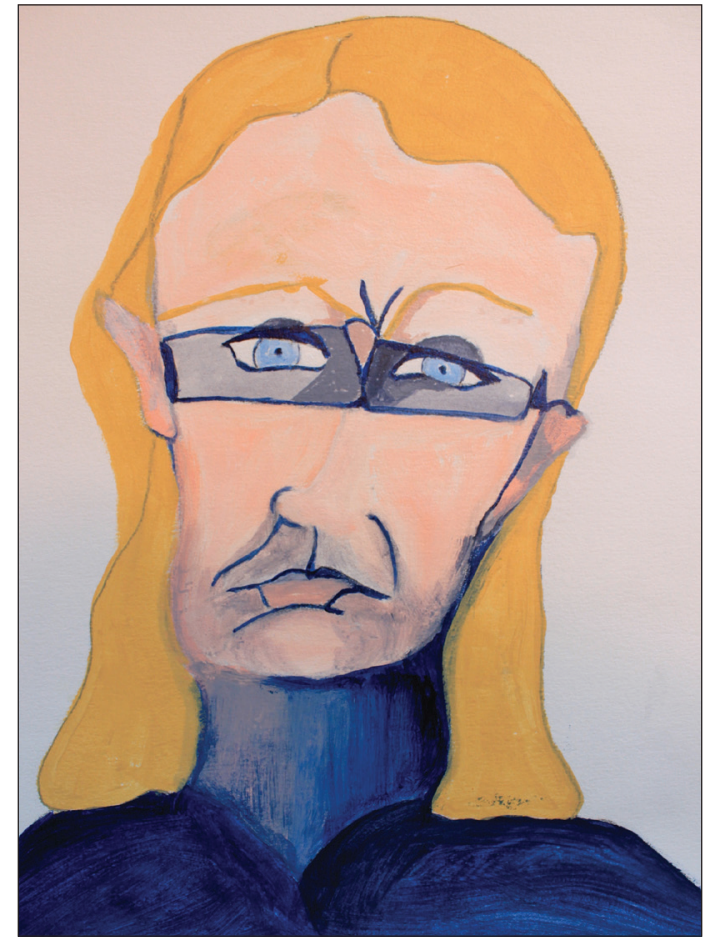

Fig. 2: Metanoia: A portrait of transformative change of heart, detail

\section{The Cenote.}

I find that I must stop and look back,

And, so, I curl into the gnarly roots of the ancient and wise mahogany tree To sleep and dream another teacher dream.

I sleep beneath the soft sounds and warmth of the rain.

It washes over me, and carries my care below into the cenote, where others wait.

Hard, cold, stone cave walls rise upward into the netherwood of the tree.

I see the weary faces and pale, skinny arms of my students.

Some float lazily, exhausted by their efforts to live,

Certain hide where they think they might be safe,

Few grasp, frenzied, at dangling roots, rock face, and tiny tendrils of hope, 
Others drown.

In my dream, I descend the slippery steps into this underworld where

The cold absorbs me.

I hear soft whispers and small sobs.

My eyes adjust to the slivers of pale green light from the faraway sun shining ridiculously above.

Amidst the ripples and the roar of conscience in my heart,

I recognise the children I have left behind.

My living theory becomes a mechanism for feedback and reflection, accountability and rigor in my work, and self-portraiture functions in somewhat the same way. In holding the mirror up myself, I cannot help but reflect upon the ideas, acts, and outcomes of the work that I do, upon the values behind the face. In using third person, I am standing back or growing into the life of the lighthouse keeper. In the following piece I come to understand my self, and my purpose as a teacherresearcher in retirement.

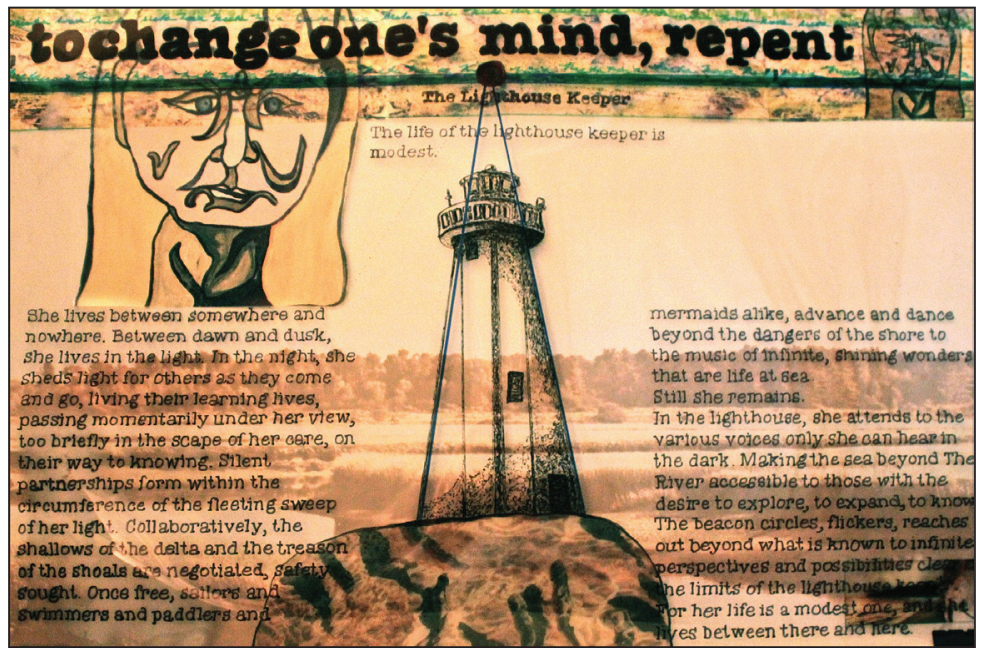

Fig. 3: The Lighthouse keeper, from Metanoia: A portrait of transformative change of heart

\section{The Lighthouse Keeper.}

The life of the lighthouse keeper is a modest one.

She lives between somewhere and nowhere,

Between dawn and dusk she lives in the light.

In the night, she sheds light for others as they come and go,

Living their learning lives, passing momentarily under her view, 
Briefly in the scape of her care, on their way to knowing.

Silent partnerships form within the circumference of the fleeting sweep of her light.

Collaboratively, the shallows of the delta and the treason of the shoals are negotiated,

Safety is sought.

Once free, sailors and swimmers and paddlers and mermaids alike,

Advance and dance beyond the dangers of the shore

To the music of infinite, shining wonders that are life at sea.

Still she remains.

In the lighthouse, she attends to the various voices she can hear in the dark.

Making the sea beyond The River accessible to those with the desire to explore, to expand, to know.

The beacon circles, flickers, reaches out, beyond what is known

To infinite perspectives and possibilities clear of the limits of the lighthouse keeper.

For her life is a modest one, and she lives between there and here.

\section{Kristen}

When I was first approached to be part of this project, and engage with portraiture as qualitative research (Lawrence-Lightfoot \& Hoffmann Davis, 1997), I was nervous due to my lack of experience as a visual artist. Although it quickly became clear that my contribution could take a different shape, that sense of trepidation never left me throughout the process. As I sat down to devise my piece, the enormity of the task struck me-how do I tell an audience, meaningfully and concisely, who I am? How do I play-act myself, not only in this context, but also as an educator every day? Am I who I say I am when others ask the question? Am I who I say I am when I ask the question of myself?

The performance piece came from my struggles with these questions and emerged from memories of theatre school, when I was first asked to present a self-study performance piece by a favourite professor, Rachel van Fossen. I worked from the starting point of gesture - the movement evoked a sense of incapacitated reaching out, inspired by Shakespeare's Lavinia in Titus and Andronicus. This was the first time that my primary creative impulse came from movement and there was a stark contrast between the physical freedom and emotional stranglehold I experienced while working.

Sharing my auto-ethnographical performance (Naidoo, 2012; Spry, 2013) with others at Teachers' Convention was difficult. In that moment, I would have loved to produce visual art instead, to let that speak for me instead of my own mouth and body. 
Nevertheless, I vomited out my text, and afterwards I was amazed at the reception we received from participants. More than that, I was humbled by the incredible, honest, and brave work that the teachers shared with us later in the workshop.

My piece, Lavinia (Because RVF Asked), crawled out of darkness in a place where I'd hoped to find light. I was confronted by the image I had crafted of myself-I wanted to see a transformation, but the same sense of powerlessness came through as it had in my first piece of auto-ethnographical research over a decade earlier. Bringing it to Heather and Judy for the first time in early November, I was discouraged by my inability to manufacture a better, stronger someone to present. Yet, this is who I was, am, and possibly, always will be. It has taken me a few weeks sitting with the piece as it was presented to realize that, unlike most of the writing and performing I do, an arts-based self-study doesn't allow me to twist and shape the performance to my desired outcome. It will be what it must be. To do authentic work I must let go of trying to control the truths that emerge. It is in this realization that I finally find a sense of liberation. Even if I have been unable to speak, define, gesticulate, present, or perform a fully realized version of myself, this work-in-progress is my legitimate self and is worth sharing.

\section{Lavinia (Because RVF Asked). (1))}

Arms outstretched,

Hands amputated by

Interminably long sleeves.

Lark's tongue sacrificed to Roman banquet,

I spat blood.

This who I hid behind

The first time someone asked me who I was.

...

That was ten years ago and

I have been hiding behind

Ill-fitting metaphors ever since -

Still-life in greyscale

Someone else's poetry

About the flight of black birds.

There is a lack of authenticity.

I thought by 32 I would have something

Unborrowed to say. 
This, too, is a portrait of myself:

Photograph of possibly-extinguished stars.

I know now the question was meant to be empowering.

I ask it of my students every day.

I encourage fluidity in their answers because,

After all,

We are always changing.

Hypocrite, I wish for stillness in my own.

\section{Engaging Empathetically With Others}

Nineteen teachers gather around tables in the conference venue for the last session on the last day of the annual Teachers' Convention. Unusually, there is a good-sized group, given the time of day, the day of the week. The room is hot, stuffy, untidy, poorly lit, and not at all the wished-for creative learning space within which to deliver an artsbased workshop. Yet, there is a palpable, happy tension. After a sketchy introduction to the whys and hows of the portraiture process, Heather, Judy, and Kristen present their creations with brief comments on the value of the experience. Then, we posed two questions:

- How do you see yourself as an educator?

- What do you value in education?

Participants were invited to create self-portraits in answer, which they would later present to the larger group. Three hands-on workshops took place simultaneously. One offered an opportunity to create a visual representation using collage and oil pastel, among other materials. The second, a light-writing workshop (Chambers et al., 2012; Sinner, 2013) gave participants a visual prompt in the form of a print or a selfie, and the freedom to write in response to it. The third was an invitation to create a spoken-word piece, asking participants to write and perform their answers to our questions.

The outcomes were surprising, yet affirming of what we suspected was possibly true. A teacher takes a journey along a career path that is fraught with tension, as well as filled with periods of joy and satisfaction. Outcomes were surprising because we found we had synchronistic experiences. Teachers reported feelings that were aligned with one another's; frustration because life gets in the way of what we want to be doing in 
the classroom; because the costumes that we are called upon to wear are not always the ones we dreamed of wearing in teachers' college; because we need more time to be doing our art in order to nourish ourselves and our practices. Also surprising and affirming was the level of engagement, risk-taking, and trust among strangers.

\section{Evidence of Engagement}

The self-portrait provides us with something substantial and tangible. It is a platform with a creative dimension that may contribute to engagement and, therefore, further understanding of tacit knowledge of the teacher, teaching, and learning. At the end of the session we understood this tacitly, however, as teacher-researchers we understand the need to be able to make a claim to validity of our inquiry. To that end, the final piece in our workshop was to ask participants for public validation. Working from Eisner's (1998) criteria of coherence, consensus, and instrumental utility, we searched for evidence of understanding, engagement, and usefulness in responses to two questions:

- In what way was the activity of creating a portrait meaningful to you?

- How might you use the idea of portraiture in your professional endeavours?

Using verbatim validation data we created métissages providing evidence of engagement and understanding.

Alice, on achieving understanding. Whenever I am feeling a particular emotion or am completely overwhelmed, it is useful to pause and reflect back on myself as an educator and to remember why I do this. Creating the portrait was useful as a moment to ground myself. It allowed me to express feelings of who l am as a person who happens to be a teacher. It was meaningful as self-reflection, but more importantly to help forge my professional identity. I have been struggling to figure out my sense of myself as a professional and this was a great beginning to find a new way of getting answers. I really love the idea of trying to see myself from a different perspective-perhaps how my students see me-and to understand how I want to be seen. Thinking about core values and education and art was a nice reminder of why I choose to do what I do. It was motivating, finding the love in something I constantly do, thinking of how self and values can be inspiration for education, and how not to lose our selves in the teaching process. The portrait helped me to look into myself, and my passion. It helped me to realize what I need for my future, to see and acknowledge how far I have come and to decide where I want to go in my career. It gave value to those early years, a form of recognition. It gave me a voice and strength. 
Dorothy, on engaging with others. The connection, the verbal confirmation of the struggles art teachers face was affirming. I need some connection. I love the arts and need to connect with like-minded professionals. It was meaningful to look at myself as an educator, to hear how fellow educators view themselves. I realized that I am not alone in my feelings; other teachers have the same or similar fears and insecurities. I was touched by other participants' experiences, and felt that they normalized my own. It was a great release to be able to share with others words and thoughts on education. I was also amazed at how many teachers have the same experience on the subject of portraits. It is related to the portraits that we, teachers, are becoming more popular on websites, YouTube, Facebook, and other social media. I enjoy writing and am starting an MA online on culture and education. Portraiture could be a start, or an idea. I have been meaning to create a vision board, and this gave me the time and space. I might use it to encourage my students to explore how portraiture reveals character and emotion. I want them to see themselves as musicians and thus, as lifelong learners. I think that I need to portray myself as such to earn their trust.

\section{Re-locating Our Learning Selves}

We are, in a sense, looking for new stars. We are looking for new seas.

We are...exploring the edges.

- E. Eisner, The Promise and Perils of Alternate Forms of Data Representation, 1997, p. 7.

We gather yet again, late on a wintery Friday afternoon to chat about our portraiture experience and our continuing engagement in artful exploration of change as feeling and form (Diamond \& van Halen-Faber, 2005). Outside, a pale sun is sliding westward, and the wind has a bitter bite. Inside, Kristen's classroom invites teacherly chat amidst stacks of novels, piles of essays, forgotten memos, and the shadow of a puddle of spilled coffee. We are more deeply aware of the complexities of location in our physical, individual, professional, personal, and psychological worlds and of the infinite points of intersection, locations we have visited in our artist/teacher/researcher selves. We do tread on capricious ground when we look within and then engage empathetically with others, but with colour and line, word and gesture we are closing distances between us, and enlarging understandings (Barone \& Eisner, 2012). Toward the end of our conversation a question arises:

- What do we now understand of teachers, teaching, and learning? 
Once again, we have braided our reflections into a métissage, a group portrait, if you will, giving voice to Hope.

Hope, on the experience of portraiture. I don't yet know all of what I have learned. Engaging creatively with our selves and our questions yields such different outcomes from a more traditional academic discourse. I did learn that art is hard for some people. Self-portraiture is a time of vulnerability, and time is another dimension. It's exposure, we make ourselves vulnerable when we share ourselves in our art. We talk about location, but it's important to look back in time. I feel more solid when I put past together with present. I am past and present in my portrait, and I engage with my portrait of my self in time.

I think my students are beautiful, and I have always tried to treat their questions as precious and valuable, spending a lot of time thinking my own questions are less significant, probably because publicly asking them would put me in a place of great vulnerability. Portraiture has meant engaging with my fears and sharing that confrontation. And, although the vulnerability is frightening, I feel safe in a circle of colleagues. Moving into the larger circle at Convention became less frightening because of the risks that teachers whom I had never met began to take. I learned that there are others like me. Normally, I work in isolation, but I see now that we are a community, sharing so much knowledge and joy for our profession. As teachers, we have moments that are very dark. As a community, we can lift each other up. We are all vulnerable, yet together we are vulnerable yet safe.

There are a lot of grey shadows on the landscape, and I know that there is a place there for me, working alongside teachers dealing with the frustration of not being able to achieve their ideals, not able to live their values in their work. I am beginning to see more clearly who I am as an artist/teacher/researcher. It has meant a huge leap, and has led me to something concrete-my doctoral proposal. My questions are valid, and I realized this in a room full of strangers sharing their own. I am inspired to create more portraits in community, most notably with my students. I have an idea for my next portrait, and I think maybe one day we could create a performance together. Portraiture is fun, and freeing, and I didn't think it would be. Now, I want to break open lots of boxes. (H. Hancheruk, J. McBride, \& K. Witczak, professional conversation, January 22, 2016)

Our interest in the answer to the question about our learning is further piqued by questions posed by Elliot Eisner (1997): 
- "How do we display what we have learned?

- What modes are legitimate?

- How shall we know?" (p. 9).

Teacher research engages us as teachers and learners, artists and researchers. Our resulting knowledge is located within our selves and displayed in self-portraits of our professional lives, reflecting challenge and efficacy, coping and commitment, role and identity in our educational endeavours. We locate and re-locate, create and re-create ourselves. The authenticity of our methods of inquiry and our claims to know is established when we present our portraits publicly, engage with others in conversations about what matters in education and about how we have come to know. We deliberately seek public validation of our claim to knowledge from participants in such conversations asking:

- In what way was the activity of creating a self-portrait meaningful to you?

- How might you use the idea of self-portraiture in your professional endeavours?

- What other comments would you like to offer to the presenters?

Finally, we submit our work for consideration for publication in scholarly journals.

As teacher researchers we have presented our understanding of self-portraiture as an experience that brings us to a point on a map, a location from which to look fleetingly behind and ahead. A portrait is a reflection of, and a reaction to, our teaching and our learning, and a point of reference at which we may engage with others on matters of mutual educational interest. We arrived at this point by following a path of reflection and action. To begin, we created self-portraits in response to the questions:

- Who am I as an artist/teacher/researcher?

- What do I value in my teaching?

- What sustains and motivates me?

- Am I who I say I am?

We reflected on what we learned from this slow, deliberate, introspective, and disturbing process of locating problems within ourselves. Because we found value in the undertaking, sharing our inquiries with each other, and subsequently with others at Convention, became our next steps. Further reflection following the workshop brought each of us to new questions, new directions. Heather has convened a group of art teachers who will meet monthly to create and share portraits, addressing the question, What sustains and motivates the art educator? Kristen will introduce 
self-portraiture into her high school English classes. Judy will look for evidence of the commitment of the lighthouse keeper using video portraits (Fancher, 2013; Wilson, 2016), asking, How might I live my values more fully in my practice? Presently, we are enjoying the relief that comes from arriving in a new location and enjoying the safety of a community of like-minded inquirers. We will continue to work imaginatively, largely intuitively, and collaboratively within and beyond our group with the purpose of taking this project forward, exploring change as feeling and form while acting as agents of educational change.

\section{References}

Barone, T., \& Eisner, E.W. (2012). Arts based research. Thousand Oaks, CA: Sage.

Chambers, C., Hasebe-Ludt, E., Leggo, C., \& Sinner, A. (2012). A heart of wisdom: Life writing as empathetic inquiry. New York: Peter Lang.

Crosswell, L. (2006). Understanding teacher commitment in times of change (Unpublished doctoral dissertation). Queensland University of Technology, Australia.

Day, C., \& Gu, Q. (2009). Veteran teachers: Commitment, resilience and quality retention. Teachers and Teaching: Theory and Practice, 15(4), 441-457.

Diamond, P., \& van Halen-Faber, C. (2005). Apples of change: Arts-based methodology as a poetic and visual sixth sense. In Mitchell, Weber, and O'Reilly-Scanlon (Eds.) Just who do we think we are? Methodologies for autobiography and self-study in teaching, (pp. 81-94). New York: Routledge.

Eisner, E.W. (1997). The promise and perils of alternate forms of data representation. Educational Researcher, 26(6), 4-10.

Eisner, E.W. (1998). The enlightened eye: Qualitative inquiry and the enhancement of educational practice. Upper Saddle River, NJ: Prentice-Hall.

Fancher, N. (2013). Re-imagining portraiture with video portraits. Retrieved from https://fstoppers.com/bts/re-imaginingportraiture-video-portraits-3536
Hamilton, M.L. (1998). Reconceptualizing teaching practice: Self-study in teacher education. London: Falmer.

Hasebe-Ludt, E., Chambers, C., \& Leggo, C. (2009). Life writing and literary métissage as an ethos for our times. New York: Peter Lang.

Lawrence-Lightfoot, S., \& Hoffmann Davis, J. (1997). The art and science of portraiture. San Francisco: Jossey-Bass.

Loughran, J., Hamilton, M.L., LaBoskey, V., \& Russell, T. (2007). International handbook of self-study of teaching and teacher-education practices. Dordrecht, NL: Kluwer.

Mitchell, C., Weber, S., \& O'Reilly-Scanlon, K. (2005). Just who do we think we are? Methodologies for autobiography and self-study in teaching. New York: Routledge-Falmer.

Naidoo, L. (2012). An introduction to definition and method: An ethnography of global landscapes and corridors. Retrieved from http://www. intechopen.co./books/

Samaras, A. (2011). Self-study teacher research: Improving your practice through collaborative inquiry. Thousand Oaks, CA: Sage.

Sinner, A. (2013). Unfolding the unexpectedness of uncertainty. Rotterdam, NL: Sense.

Sontag, S. (1996). Against interpretation. New York: Picador. 
Spry, T. (2013). Performing autoethnography: An embodied methodological praxis, Qualitative Inquiry, 7(6), 706-732.

Thornton, A. (2013). Artist researcher teacher: $A$ study of professional identity in art and education. Chicago: University of Chicago Press.
Whitehead, J. (1993). The growth of educational knowledge: Creating your own living educational theories. Bournemouth, ENG: Hyde.

Wilson, R. (2015). Video portraits. Retrieved from www.robertwilson.com/video-portraits/

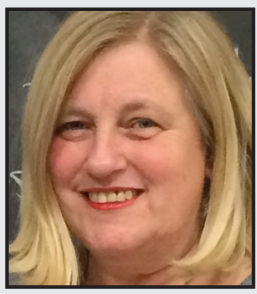

Heather Hancheruk, BFA, Dip.ED, MA is a 30-year veteran art teacher. She has taught both in the north, in Chibougamou, Quebec, and south in Nassau, Bahamas. She presently teaches near Montreal and is pursuing a PhD in art education at Concordia University. Her research interests include teacher education and professional development, life history research and veteran art educators. Heather's mixed media collage/paintings reflect her life and are a part of her arts-based research adventures.

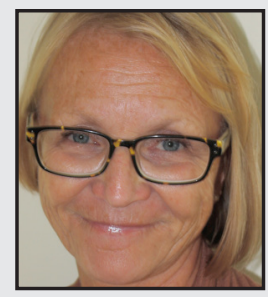

Judith McBride, $\mathrm{PhD}$, is a retired special education teacher and former lecturer at McGill University's Faculty of Education. She is a Hilroy Fellow, and has been recognized for academic excellence by the Canadian Psychological Association. Judith has volunteered with teacher researchers in Canada and abroad, and is currently supporting teacher inquiry projects in various contexts. Her research interests include arts-based, narrative, and self-study inquiry for teacher professional development.

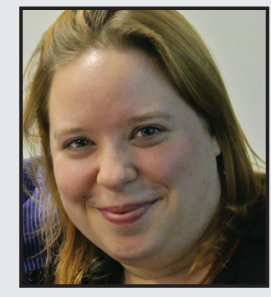

Kristen Witczak, BFA, BEd, is an early-career English teacher and arts educator with a background in the performing arts. She has a BFA in Theatre from Concordia University and completed her teacher training at OISE/University of Toronto. She teaches a happy mix of Grade 7 and 11 students at Saint Lambert International High School in suburban Montreal. Kristen's research interests include performance ethnography, narrative inquiry, arts-based research, and self-study. She is looking forward to undertaking graduate studies in the near future. 